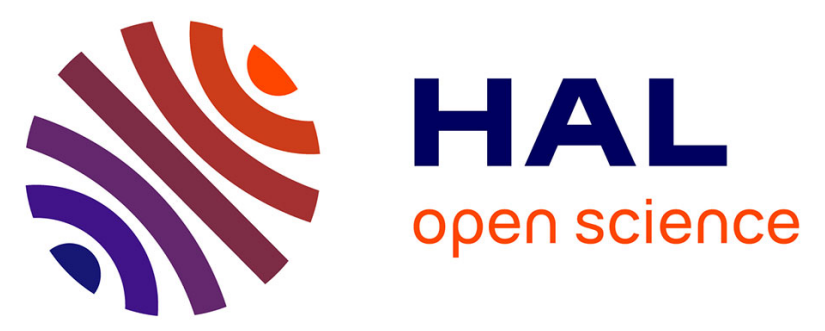

\title{
The extended concept of littoral active zone considering soft sediment shores as social-ecological systems, and an application to Brittany (North-Western France)
}

Lucia Fanini, Christophe Piscart, Enzo Pranzini, Christian Kerbiriou, Isabelle Le Viol, Julien Pétillon

\section{To cite this version:}

Lucia Fanini, Christophe Piscart, Enzo Pranzini, Christian Kerbiriou, Isabelle Le Viol, et al.. The extended concept of littoral active zone considering soft sediment shores as social-ecological systems, and an application to Brittany (North-Western France). Estuarine, Coastal and Shelf Science, 2021, 250, pp.107148. 10.1016/j.ecss.2020.107148 . hal-03102669

\section{HAL Id: hal-03102669 \\ https://hal.science/hal-03102669}

Submitted on 22 Feb 2021

HAL is a multi-disciplinary open access archive for the deposit and dissemination of scientific research documents, whether they are published or not. The documents may come from teaching and research institutions in France or abroad, or from public or private research centers.
L'archive ouverte pluridisciplinaire HAL, est destinée au dépôt et à la diffusion de documents scientifiques de niveau recherche, publiés ou non, émanant des établissements d'enseignement et de recherche français ou étrangers, des laboratoires publics ou privés. 
1 Title:

2 The extended concept of Littoral Active Zone considering soft sediment shores as social-ecological

3 systems, and an application to Brittany (North-Western France)

Authors:

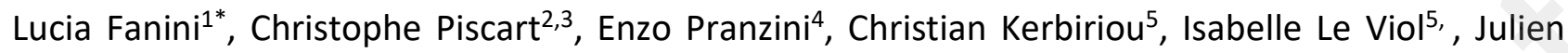

7 Pétillon ${ }^{2}$

${ }^{1}$ Hellenic Centre for Marine Research, Institute of Marine Biology, Biotechnology and Aquaculture

112 Université de Rennes, UMR CNRS 6553 ECOBIO, F-35000, Rennes, France

${ }^{3}$ CNRS, LTSER "Zone Atelier Armorique,", Rennes, France,

$13{ }^{4}$ Dipartimento di Scienze della Terra, Università di Firenze, 50121 Firenze, Italy

${ }^{5}$ Centre d'Ecologie et des Sciences de la Conservation (CESCO), Muséum, national d'Histoire naturelle (MNHN), Centre National de la Recherche Scientifique (CNRS), Sorbonne Université, station marine, Concarneau, France

*Corresponding author. Email : lucia@hcmr.gr

Abstract:

This paper applies and extends the concept of Littoral Active Zone (LAZ) of sandy beaches as a relevant dimension to observe and manage this socio ecological system. The LAZ is a dynamic zone where exchanges across land and sea occur, and this concept was initially proposed on a geomorphological background only. However, to achieve full relevance and timely address management choices tied to the functioning of soft sediment shores, it became appropriate to extend its consideration to both the ecological and social templates co-existing on the same physical unit. Current paradigms around the concept of LAZ were used as a background to organize information from different disciplines and extend the concept to different soft sediment shores (mostly sandy beaches and salt marshes), towards a global, integrated relevance of the concept.

As a test for this approach, we 1) structured information on the biophysical and social templates around the concept of LAZ, 2) extended it to salt marshes and 3) applied it to the case of the Breton coast for a practical test on information organization. Such an exercise highlighted key characteristics of the LAZ using a multidisciplinary approach, but also gaps to be filled when 
targeting research, perception, communication, sustainable use and management of the LAZ as a functional unit.

\section{Study approach}

The background information (paragraphs 2-5) was structured by gathering current paradigms and definitions around soft sediment -when concepts are still debated, versions presented are backed by references and related empirical data. The call for extension of the concept of sandy beach, opening options for landscape scale considerations, is here answered by considering salt marshes (motivations detailed in paragraph 6), hence the use of "soft sediment shores". Human-modified beaches are included in the background (paragraph 7), assuming that this is a most common condition, in a context where sandy shores are affected by human-driven phenomena -though to a different extent- at global scale. The social template of the Littoral Active Zone is described on such background, and defined physically in space and time to reach the depiction of its boundaries (paragraph 8). We finally provided detailed information for the case of Brittany (paragraph 9), utilizing the standard structure of a social-ecological system as two templates (the social and ecological one), inter-connected by adaptive management and ecosystem services. To this aim, information comprehends not only scientific papers but also grey literature and references to ongoing projects. Conclusions are an open invitation to consider the LAZ and its diverse components as the proper dimension to approach and manage systems connecting land and sea.

\section{Current paradigms on sandy shores: patterns and processes across the Littoral Active Zone.}

Sandy shores are ecotonal systems connecting land and sea. Their definition is slightly different depending on the discipline considered. For instance, in geomorphology the "beach" goes from the depth of closure to the upper limit of the runup under extreme waves, and the dune is excluded from the sandy shore definition sensu stricto (Komar, 1989).In ecology, sandy shores consist of three entities along the land-sea axis: surf zones, beaches and dunes. Each one of them is characterized by distinct organism assemblages, tightly related to the physical constraints of the microhabitats they inhabit (McLachlan and Defeo 2017 and references within). A unifying concept is that the different zones along the land-sea continuum are connected by a constant exchange of energy and material, including boulders, pebbles, gravel, sand or silt (see Wentworth, 1922 for sediment size categories). Hence the concept of Littoral Active Zone (LAZ) (Tinley, 1985) was proposed to define a soft-sediment coastal system, with boundaries identified by the effects of the waves (seaward) and aeolian (landward) transportation of sediment. Sediment is in fact being 
exchanged across the geomorphic system of the $L A Z$, in a dynamic process. This led to the use of sediment budget (Komar, 1989) for sandy shores management purposes: the concept of LAZ referred to the littoral geomorphology and proposed the management of a unit including both marine beach/surf zone and terrestrial dune ecosystems. However, such a conceptual framework has not been fully applied to the biotic component of the system, where multi-level exchanges (of energy, material and nutrients) occur along the same unit (after McLachlan and Defeo, 2017):

- Primary producers (surf phytoplankton, seagrasses, benthic microflora, pioneer and dune vegetation);

- Primary consumers (dominated by bacteria, peracaridans, annelids, mollusks, insects);

- Predators (dominated by birds, coleopterans, spiders, crabs)

- "Temporary" i.e. only spending within the LAZ a key stage of their life-cycle: planktonic larvae and juvenile stages; nesting or migrating birds; nesting turtles.

While research on sandy shores provided a solid background with respect to morphodynamics, current knowledge related to biotic components indicates that they are 1) mostly physically driven and 2) generally known in terms of patterns, but with a gap in knowledge concerning the processes shaping the patterns measured (Defeo and McLachlan 2013).

\section{Across-shore dimension.}

Along the LAZ, at a dimension defined as "mesoscale" in ecology of sandy shores (i.e. "within beaches"), both water-breathing and air-breathing organisms can be found, following zonations which fluctuate in space and time linked to habitat availability (McLachlan and Jaramillo, 1995). Indeed, the beach is the one entity of the LAZ in which both water-breathers and air-breathers cooccur (Defeo and McLachlan, 2005), while surf zones are exclusively inhabited by water-breathers and dunes by air-breathers. Dugan (2013) proposed the concept of "envelopes" for the beach entity, i.e. spatial units affected by temporal units varying daily-to-yearly. This explained macrofaunal patterns better than the mere "beach width" variable. Scapini et al. (2019) remarked on the relevance of behavior in the macrofauna zonation patterns, with plasticity as the main adaptation to recover and maintain a suitable habitat. By extending the analysis to the whole LAZ, the characteristic mobility of substrate is the main biotic driver that shapes microhabitats and to which the fauna adjusts their behavioural responses. 
Each LAZ across-shore relates to an along-shore unit (perpendicular to the land-sea axis), which can be called the physiographic unit, sedimentary cell, or beach units. Along-shore dimension is defined by natural headlands or man-made structures overpassing the depth of closure, i.e. the depth to which the cross-shore sedimentary exchange is insignificant and which is identified where bathymetric profiles repeated over time are connected (closed) (Hallermaier, 1977). By considering the dune as a part of the Active Zone, units can also overpass headlands (e.g. locations in which transgressive dunes have climbed escarpments and passed the headlands, Pye and Blott, 2020). Embayments and pocket beaches, with boundaries generating turbulence and rip currents at their edges, are easy to identify as units. Within units however, as e.g. in the case of extended beaches, exposure and longshore currents may affect the sand mobility (Komar, 1989); hence a beach can hence include a continuum from deposition to erosion, confusing the identification of units along-shore (Carter, 1988). Also mixed conditions such as sparse rocks present on sand substrates, affect the flow of energy and material within units. Dynamics become more relevant in the case of wrack inputs ashore, driving the spatio-temporal patterns of stranding. In ecology, given the large amount of studies focusing on sand-only conditions, conditions of periodical inputs of stranded material are often overlooked. However, they are important in terms of dynamics backing the biotic patterns measured ashore. In general, beach fauna patterns present land-like characteristics (McLachlan and Defeo, 2017 but also see Defeo and McLachlan, 2011), with single beaches ("ecological mesoscale") remaining an essential unit for analysis.

In summary, the paradigm of sandy beaches as physically-controlled environments, when applied to the mobility of the substrate as LAZ characteristic, highlights the following features as keys for resident biota:

1) Pore space for the development of rich interstitial fauna dominated by bacteria, protozoans and meiofauna. The interstitial system processes organic materials flushed into the sand and returning the inorganic nutrients to the sea (Pearse et al., 1942).

2) Incohesive substrate as a driver of burrowing mechanisms of macrofauna. "Dealing with substrate" defines essential traits of organisms inhabiting the surf zone (Gibson et al., 2006). On the supralittoral area, substrate and non-substrate modifiers can be found, whose presence largely depends on substrate granulometry and related water retention, as well as on allochthonous inputs (e.g. seagrasses mats) (Pérès and Picard, 1958, Sassa and Yang, 2019). 


\section{Vertical dimension (depth).}

133 The depth of sediment mixing is rather difficult to define, though it is generally considered from the physical point of view as the layer of sediment mixed by waves over a specific time interval. It depends on wave energy and sediment size, and influences the substrate-related activities of benthic fauna. Resident bivalves were estimated to completely re-work the first $5 \mathrm{~cm}$ of fine sediment, producing fecal pellets moved by the currents that caused high turbidity and a sediment loss of about $30 \mathrm{~cm} /$ year (Risk and Moffatt, 1977). The biotic feature which best describes the interaction with the vertical dimension is the biological trait of bioturbation that is functionally relevant for the ecosystem (see e.g. van der Linden et al., 2012). While the relevance of burrowing for organisms inhabiting the benthic of marine and lower littoral was thoroughly investigated (see e.g. Gibson et al., 2006; Che and Dorgan, 2010), the upper littoral system was overlooked and only recently explored (Sassa and Yang, 2019, Celentano et al., 2019).Specialist and generalist species can be defined with respect to burrowing patterns: substrate specialists such as cirolanid isopods are burrowing in fine sand only and within a narrow range of water saturation conditions (Giménez and Yannicelli, 2000), while generalists such as ghost crabs can display a range of shifts in zonation and behavior across the littoral and cope with severe impacts, e.g. those from off-road vehicle driving, by shifting burrowing behaviour (Gül and Griffen, 2018).Ecological categories can also be defined within single taxonomic groups based on their burrowing capabilities(Lowry and Fanini, 2013). Burrowers and non-burrowers can coexist on a soft littoral substrate, yet have a different reaction to substrate disturbances, such as wrack removal (Fanini and Lowry, 2016).

\section{The concept of LAZ extended to other interface systems: Salt marshes.}

154 Salt marshes are intertidal environments also characterized by soft sediment. They have been included in recent conceptual frameworks regarding human-environment interactions on softsediment coastlines, namely as low-energy extreme environments (Dugan et al., 2018 and within). Such conceptual extension would allow, as a consequence, the broadening of questions from mesoscale (in its ecological meaning) to landscape ecology (Schlacher et al., 2015).Sandbanks of

159 salt marshes are also featuring the flood and drain of salt water, though with a higher material 160 retention, sharing most abiotic and biotic characteristics of sandy beaches. The identification of a 161 LAZ for salt marshes can be based on the features shared with sandy littoral zones, such as: 
1) The exchange of energy and material landwards and seawards. The low and high marsh behave in this respect as the beach and dune continuum. Salt marshes would represent systems with low-energy exposure (see also Dugan et al., 2018), low mixing of the substrate -a feature likely enhancing the role of biota in sediment mixing and making it available for tidal current transport. In tidal channels however, physical processes might be dominant.

2) The biotic components of salt marshes, representative of a sea-land interface with the same dominant categories of species found on sandy littorals. Assemblages are defined by abiotic filtering and biotic interactions, likely changing with saltmarsh succession (Scharma et al. 2012). Where the flood frequency is high, marine species gain relevance (see e.g. Kneib 1984, Levin and Talley 2000), while high marshes are hosting more terrestrial fauna (Pétillon et al. 2008), whether specialist or temporary.

3) The effect of salinity: many terrestrial species like spiders display better survival and increased fitness under non saline conditions (see e.g. Foucreau et al. 2012) while few taxa act like marine species, i.e. with enhanced survival and fitness when exposed to salt stress (see e.g. talitrid amphipods, Persson 2001).

4) Like beaches, salt marshes function as "islands", from both population (genetic diversity) and assemblage (species richness) points of view (see e.g. Desender et al. 1998 and Rey and Strong 1983respectively). Furthermore, patches of vegetation within a landscape matrix dominated by another plant species also act as "islands within islands" (Puzin and Pétillon 2019).

5) The provision of a range of ecosystem services, most relevant being: fish nursery, trophic enrichment for aquaculture, aesthetic value for real estate and attenuation of waves (Adams 2020). With respect to sandy beaches, salt marshes are typically less affected by direct human impacts such as tourism. Yet, they are subjected to a range of anthropogenic activities such as sheep grazing or mowing.

As low-energy systems, sand banks of salt marshes would indeed represent an extreme condition of dissipative beaches (McLachlan et al., 2018), with lower turbulence and smaller substrate grain size allowing the most benign conditions to biodiversity and life-history traits of resident populations. An extended surf zone would allow for richer surf-fish assemblages. Finally, in a 
metapopulation perspective, they would act as sources like flat and dissipative beaches (Defeo and McLachlan, 2013) -as opposed to oceanic exposed, reflective beaches acting as sinks.

An opportunity to test the "sandy beach model" on other interface systems would increase the relevance of coastal studies, specifically addressing the role of environmental heterogeneity in granting refugia, resilience and diversity to the coastal system (Schoeman et al., 2014). Even though merging fields which traditionally have been kept separated is challenging (Orr et al., 2020), the relevance of LAZs is a suitable common denominator for the approach to different interface systems.

\section{Social-ecological systems: human modified littorals.}

The anthropogenic modification of the shoreline relates to different aspects. Coastal squeeze (Defeo et al., 2009; Elliott et al., 2019) is the trend resulting from the combination of actions undertaken to first extend and then preserve the infrastructures and properties on the land-side, coastal erosion and sea-level rise on the sea side. Changes in the near future are expected to occur on and strongly affect the LAZ: urbanization, increase of population on the littoral, increasing demand for recreation, climate change-related phenomena, and will likely affect its patterns and processes. To address coastal squeeze, two classical actions are: 1) retreat and 2) defend (Williams et al., 2018). Considering coastline retreat implies the knowledge of land uses behind the LAZ, i.e. a likely difficult ecosystem analysis at short- and mid-term scales (though, different perspectives based on species-environment models are proposed by Mendoza-Gonzales, 2013). As a general assumption, when the natural boundaries of the LAZ are preserved (particularly the sand reservoirs and the vegetation) the system can resist stress or recover from stress (resilience), acting as a natural buffer against storms and natural erosion (see e.g. Sutton-Grier et al, 2015). "Defend" implies human interventions which are directly and irreversibly modifying the LAZ, for instance: hard infrastructures introducing fixed elements in a mobile sediment environment transform a sand coast into a rock one -this is also true for non-defense hard infrastructure, such as harbors, piers and artificial reefs for fishing. This should interrupt the continuum, defining new beach units in terms of both abiotic and biotic components (Fanini et al., 2009; Dugan et al., 2018), and beaches increasingly becoming man-made landscapes (a temporal follow-up provided by Nordstrom, 2014). The extension of infrastructures on the sea side was defined as "ocean sprawl". Hypotheses on multi-scale effects of ocean sprawl on soft sediment coastlines were formulated (Heery et al., 2017) yet they remain to be tested, especially regarding the effects on biota and 
dynamics such as e.g. connectivity. For instance, as the longitudinal connectivity (structural and

225 functional) of LAZ biota and the role of marine wrack inputs are poorly studied, the research on 226 the effects of man-made fragmentation is likely to be built on missing baselines. Finally, human 227 intervention can relate to the stabilization of dunes via introduced plant species, see e.g. the use 228 of Casuarina ssp. and related interference with sea turtles' nesting(De Vos et al., 2019) or the 229 effects of the plant Ammophila arenaria replacing native species in Australia (Bird, 2000).

230 Human activities occurring on the LAZ can also be periodical and/or with reversible effects, such as 231 direct trampling and wrack removal. These kind of pressures are mostly related to recreation and 232 are sharper in case of seasonal use of the resource beach. On one hand, these impacts are related 233 to substrate changes and depletion of organic input, mainly affecting the fauna inhabiting or 234 foraging on the beach and upper part of the $L A Z$, where wrack inputs are a relevant feature and 235 sustain dynamics of faunal succession (Dugan et al., 2011). Supralittoral fauna can in fact actively reach the wrack when available, but also display opportunistic diet shifts given the patchy and discontinuous availability of the resource(Olabarria et al., 2007, Colombini et al., 2000).This latter aspect is however exacerbated by human actions(reviewed by Dugan and Hubbard, 2010). On the other hand, recreation is connected to a primary role of the landscape, including substrate characteristics as one important feature (Pranzini et al., 2018). The presence of stranded material

241 (paradigmatic are the cases of Posidonia banquettes in the Mediterranean Sea, and Sargassum in Mexico and Caribbean Islands) is perceived as negative for tourism and consequently local authorities/managers are actively removing stranded material, at least seasonally. It is worth remarking that along the range of impact affecting soft sediment coastlines as social-ecological systems, the sand bank of salt marshes would represent a lower impact level, allowing for a "compare and contrast" approach.

Though, regulations and management add a mismatching layer to the system, with the blanket term 'littoral' including the non-aligned definitions based on different disciplines, and encompassing a range of environments with specific features and processes (McLachlan and Defeo, 2017).

\section{LAZ as a relevant functional social-ecological unit.}


To summarize the concept of social-ecological unit and tie it to the LAZ, we apply the conceptual scheme proposed by Bretagnolle et al., 2019 (Figure 1).The reasons of identifying the LAZ as a socio-ecosystem are rooted in two backing concepts:

- The consideration of mobile substrates, physically defining the LAZ and common denominator across social and ecological template is a relevant background for such an integrated approach.

- The consideration of time as fourth dimension, with the identification of different temporal scales highly depending on the phenomena which should be observed. The proper selection of a time scale will allow an understanding of changes across both templates.

[Figure 1. Littoral Active Zone as social-ecological system (definition of the templates after Bretagnolle et al., 2019). The boundaries of the system are considered in the three dimensions physically defined in this paper.

The social template of the LAZ is characterized by a strong land-bias. While there is no human resident on the $L A Z$, there is a physical direct use of the zone, as well as regulations in place to define such use. At the same time, citizens have been indicated as "missing layers" in marine spatial planning (Martin and Hall-Arber, 2008), neglecting a fundamental component of the social template. Perceptions and attitudes of citizens are powerful drivers of the system. Hence, providing literacy and awareness can bring considerable change. However, when referring to the Littoral Active Zone as defined, this may indeed be a difficult background for the creation of awareness, in terms of both biota and physical processes. Beaches appear as piles of sand inhabited by cryptic and non-appealing key species (Dugan et al., 2010). Even high rates of endemism do not result as appealing as iconic species, probably because most animal species are composed of small and colorless (invertebrate) species (Harris et al., 2014; Leandro et al. 2017). Iconic species are usually LAZ facilitative and were therefore found to be less responsive to changes than resident fauna (Schoeman et al., 2014), even though may be key for conservation (McLachlan et al., 2013).Another common issue is the perception of what component of the stranded material is really litter: attitudes towards stranded wrack are generating conflicts between conservation and recreation for decades. A few key drivers acting on the LAZ are summarized and represent potential conflicts between conservation vs. exploitation.

Tourism. Beyond the budgetary consideration applied in geomorphology (input and output estimates), square meters of substrate are a unit used for the estimate of surface available for 
seaside activities that can be given a market value. In California, for every \$1 spent on beach nourishment in Miami, the federal government expects to collect $\$ 320$ in tax revenues from beach tourism (Houston 2008), while a conservative estimate of $\$ 587$ million per year is estimated as value of beach visits in Queensland, Australia (Rolfe and Gregg, 2012).In general, the "Big five" for beach attractiveness are: Water colour, Beach cleanliness, Safety, Facilities and Scenery (Anfuso et al., 2018). The choice of a given place as a tourist destination is driven by both domestic and international market pressures, hence mainly external to the LAZ. In this sense the use of Blue Flag is a most relevant example of driver, considering environmental quality along with social parameters (such as safety for swimmers) within the same set of desired conditions. The Blue Flag award was found to increase market competitiveness of beaches (Dodds and Holmes, 2020).However, the concept is often confused with touristic promotion, and increasing information about underlying criteria would be required (Lucrezi et al., 2015, but see McKenna et al., 2011). This stresses again the importance of citizen literacy and awareness in exploiting the full potential of an existing and well established tool.

Cultural value. This is a value often overlooked, in spite of being a potentially powerful driver of decision making. There is a clear context-dependency related to the cultural value of littoral active zones, depending on the history, social attitudes and size of population benefitting from it (Daniel et al. 2012). Processes modifying cultural assets, and specifically impacts (e.g. plastics, nourishment, urban sprawl) can be a leverage to engage citizens. Attitudes depend on cultural value and historical use of the beaches, with biased choices stemming from human expectations on sandy shores (mainly driven by recreation, real estate values, etc.), rather than on the balanced representation of the system. This finally leads to unpredictable long-term consequences (Elliott et al., 2007).There is an increase in different programs (among them, citizen science programs -Earp and Liconti, 2020) and measures proposed by NGOs and land managers to re-connect people to the ecosystem, both with respect to its functioning as a whole (in the case of LAZ phenomena such as trophic network, erosion) and targeted conservation issues (ecosystem and/or species-focused approach). It is too early to describe LAZ-based experiences, as many of these actions are just starting, though platforms such as Ocean Best Practices and European Citizen Science are

314 Fishery. This category holds a commercial interest, which, around soft-sediment shores, is preparing the environment for sharing them.

\footnotetext{
generally related to subsistence, recreational or commercial (listed in an increasing spatial scale of
} 
relevance), though they usually co-occur (McLachlan et al., 1996). While subsistence relates mainly to direct harvesting, e.g. of clam populations, and even when commercial, it is still related to the artisanal and local levels, commercial fishery extends from the surf zone to the pelagic one, with nursery areas for pelagic and demersal species. Lack of management plans encompassing the whole species-habitat creates severe impacts, see e.g. the sequential fisheries. These are spatially segregated fleets affecting different components of the life stage of one or more fish species (Seijo et al., 1998).

Connected templates. In the extended LAZ concept, we link the social template to the biophysical template with the adaptive management loop. In practice, in the governance of LAZ, there might be mismatches between ecological units and administrative/managerial ones. The latter ranges from international to national to local, and can be site-specific. An ubiquitous and transdisciplinary risk is the excessive consideration of recreation at the expenses of the other components. The perceived conflict "conservation vs. exploitation" is also expected to harshen in a context of climate change eroding the available resources. Even though scientific input has been used to set standards, there has been inadequate integration of costs of management and benefits of controls (McLachlan and Defeo, 2017).For instance, eventual discrepancies between the environmental degradation perceived by the public and policy-makers with those identified by scientists will need to be identified and evened up via information sharing. Several countries have specific requirements for developing and implementing littoral protection; the immediate priority is to avoid further development on areas likely impacted by erosion in the future, measures are hence based on coastal setbacks, allowing for retreat, fixing a minimum distance from the shore for new buildings. There is a huge variability worldwide regarding this distance (from 5-15 $\mathrm{m}$ at Bahamas to $300 \mathrm{~m}$ in Denmark; though $100 \mathrm{~m}$ is the most common distance allowed. Depending on the geomorphology of the coastline, in some cases such as Australia elevation becomes the parameter to set limits on). Though, the way different references points are defined for "shore" e.g. low water mark; line of stable vegetation; etc. are adding further variability (see Simpson et al., 2012).

The loop between biophysical template and social template is representing the challenge of ecosystem-based governance. Even though the set of ecosystem services provided by sandy littoral zones is broad, it is mostly localized and occurs within the LAZ, and tightly related with coastal management units (Sardà et al., 2014). The fluid nature of the system is challenging the attempts to estimate and valuate ecosystem services, e.g. mapping and land cover changes, a powerful tool 
for (Burkhard et al., 2012) could not be applicable in a context of an always varying extension of the area, and mobile substrate. In particular, if the littoral area -or the LAZ as we proposed- is widely neglected in the international legislation as a management unit. Instruments for integrated approaches to standardise development and management include a triple bottom line (TBL) approach, a well-established framework with multiple stakeholder input used to account for social, economic, and environmental impacts of management options. This should produce ecologically meaningful and protective standards for any jurisdiction which could effectively be applied to the LAZ.

\section{Application of LAZ extended concept to a coastal region: the case of Brittany}

As a test for this approach, after structuring the information on biophysical and social templates around the concept of LAZ, we applied it to the coast of Brittany, filling with detailed information related to the templates and the LAZ of a so far overlooked case, such as European macrotidal shores. Questions to support further research are listed as part of the interfaces between templates (ecosystem services and adaptive management: Table 1).

The coastline of Brittany represents $33 \%$ of the French (excluding overseas) coastline. The study of its soft sediment shores is however overlooked. As mentioned above, this is not only a regional need, but also a requirement to test current ecological paradigms by adding inputs from macrotidal conditions (see McLachlan and Defeo, 2017; Fanini et al., 2020). Indeed, the high variability and case-dependency of littoral ecology should warn against the use of "one size fits all", and the concept of LAZ as a unit should help in tackling the biophysical and social dimensions, in which phenomena can be observed and described reducing the bias due to mismatching scales. The structure of information in biophysical and social templates (Figure1) allows for the identification of those features supporting the interfaces between templates, sustaining their inter-connection via a double loop. A set of actions is recommended to assist with the implementation of social-ecological governance, integrating templates along their interfaces:

\section{Ecosystem services interface (from biophysical to social).}

- Consider relevant beach units including substrate characteristics. The Breton coastline is heterogeneous with a mix of rocks and soft substrates as well as different tide types (from macrotidal regimen to tidal flats).A flexible yet biophysical-based unit such as the LAZ would be a meaningful framework for mapping management and related effects.

- Focus research on connectivity taking into account the conditions of macrotidal shores, the presence of cricks, and human modification of the coastline. Cases such as: species 
distribution ranges (e.g. the coastal spider Halorates reprobus reported to have the Southern boundary of its distribution range in Brittany, Courtial and Pétillon, 2016; Crambe maritimum and its clustering along European coasts, Kadereit et al., 2005) and/or species disappearance (such as the carabid Eurynebria complanata and the earwig Labidura riparia Courtial 2013) could open paths to the study of structural and functional connectivity based on the heterogeneity of the coastline, backing the recorded patterns with their drivers, and provide inputs to conservation strategies.

- Use the available knowledge and resources to define the role of wrack and of green tides on the LAZ. Answer questions related to the interactions between substrate (cricks, soft bottom)and stranded material interaction; test hypotheses (so far general such as e.g. in Trewhella and Hatcher, 2015) on the role in the trophic chain of amphibians and mammals (including bats and mustelids, so far overlooked in studies) foraging on beach wrack, and/or on local fauna successions in the dynamic process of stranded material decomposition (as reported by Colombini et al., 2000 for tropical shores). Disentangling the temporal dimension of cast wrack and the fauna depending on it, would greatly support management actions.

- Consider salt marshes as extremes not only environmental (i.e. lowest energy soft sediment systems), but also in terms of social use (i.e. lowest human impact) and include them in analyses across a set of conditions, from open oceanic to sand banks of salt marshes.Brittany hosts one of the largest intertidal areas worldwide, with the Mont SaintMichel Bay extending to Normandy on the East, and would be a paradigmatic example in this respect.

\section{Adaptive management (from biophysical to social).}

- Consider the current littoral protection framework and the objectives of its establishment: in France, all littoral areas are concerned against urbanization-artificialization by the "Loi Littoral" (law n86-2, 3 January 1986). The law relating to the development, protection and development of the coast, known as the coastal law, is a French law which aims to regulate 
the development of the coast for the protection of the excesses of real estate speculation and to allow free public access to coastal paths. The limit to the building in a buffer strip of $100 \mathrm{~m}$ along the littoral is included within this legal framework. Beyond a setting against unbridled urbanization, the law mentions: "The implementation of a research and innovation effort focusing on the resources of the coast"; The sustainability of an aquatic economy: "the preservation and development of economic activities linked to proximity to water, such as fishing, marine farming, port activities, shipbuilding and repair and maritime transport"; The sustainability of a non-aquatic economy: "the maintenance or development, in the coastal zone, of agricultural or forestry activities, industry, crafts and tourism.". However, resources and implementation of these aims rely on other actors, which for Brittany are mainly (in terms of surface concerned): 1) the Natura 2000 network (Habitats

Directive 92/43/CEE and Bird Directive 2009/147/CE; https://ec.europa.eu/environment/nature/natura2000/index en.htm ), an European network based on local management plans. In France, it is mainly base on a contractual approach for the management of the sites, and counts on steering committees including main stakeholders (fishermen, farmers, landowners, users and experts) with the ultimate goal of maintaining or restoring a good conservation status in accordance with the protection of species and habitats of European interest. A large part of the Breton littoral is covered by Natura 2000 areas (http://carmen.developpement-

2) the "Conservatoire du Littoral" http://www.conservatoire-du-littoral.fr/, a governmental agency who since 1975 acquires littoral areas to protect them against artificialization (currently they own around $15 \%$ of French coast). As a result, the most sensitive coastal areas are under legal protection against impactful activities (e.g. vehicles on the littoral), while remaining open to public. Activities at the sites have to be carefully managed by local partners. 3) Natural Heritage Park, Man and Biosphere Reserveand Marine National Park are large areasassociated with cultural values and traditional natural resource management systemswhere the main goal is a sustainable use of natural resources (IUCN protected areas Category VI Locke and Dearden 2005)

- Make best use of the impressive availability of data from LTERs and from specific groups (e.g. ornithologists). The information has to be communicated to the coastal zone users in the form of specific campaigns, focusing on the LAZ as a continuum and land-sea interface. Specifically, raise awareness on the role of wrack and in particular of Ulva to sustain 
governance with respect to a debated topic and involving possible human health issues. Within a vision of beach users engagement and promotion of conservation, implement actions targeting perception, e.g. investigating on the public awareness and attitudes towards LAZ resident fauna (Leandro et al. 2017); debunk incorrect perceptions (e.g. beaches seen as piles of sand), and counteract the standardization of beach scenery (see Anfuso et al., 2018), acknowledging and valuing the individual "personality" of each beach.

- Capitalize the existing citizen monitoring programs to provide standardized, high quality data at LAZ level. The example of California, where major changes in space and time were identified (e.g. Hubbard et al., 2014, reporting local extirpations) due to their long-term and large scale perspective, could be supported by fine-scale citizen monitoring actions. The very same actions could also facilitate the integration of conservation issues in management of shoreline and ultimately the empowerment of volunteers (but see the aims of Plages Vivantes, a citizen science program of the National Museum of Natural History, Paris www.plages-vivantes.fr).

- Identify iconic species related to the LAZ (birds, including migrating and wintering birds, are better candidates, at least on a temporal base. One example of ongoing program is the specific regional action plan "PRA" "Gravelot à collier interrompu" (Charadrius alexandrinus) for which there is a specific (Brittany) regional action plan "PRA" www.bretagne-vivante.org/Nos-actions/Connaitre/Les-oiseaux/Especes-rares-etmenacees/Le-Gravelot-a-Collier-Interrompu/Un-plan-regional-d-action-pour-le-Gravelot-acollier-interrompu-en-Bretagne). The connection of iconic species with the significance ofLAZ for the completion of their life-cycle would allow for ad hoc campaigns maintaining a species-environment focus. Under a management perspective, the information related to iconic species is also a parameter proposed by McLachlan et al. (2013) for the allocation of management priorities in the case of beach mixed use, hence this information would finally

- Consider LAZ units for Driver-Pressure-State-Impact-Response studies and their outcomes as governance support (see e.g. Pirrone et al., 2005), keeping the environmental mesoscale as the appropriate level to efficiently detect DPSIR. The mosaic of geomorphologies and uses found in Brittany would in fact allow for the isolation of different phenomena at the same spatio-temporal scale.

- Sustain the current asset of littoral protection, understanding the underlying mechanisms which connect the range of tools available for sustainable management. This could reveal 
mismatches between theoretical and practical frameworks. With respect to the Blue Flag for example, 35 beaches (including one lake) and ten harbours were awarded in 2020 in Brittany (maps at https://bretagne-environnement.fr/dataset/communes-et-portslabellis\%C3\%A9s-pavillon-bleu-en-bretagne/resource/895be2a9-3280-4f83-83af). However, most of the sites are not located in protected areas. This is likely due to the fact that Blue Flag awards in France are mainly perceived as advertising for mass tourisms. Plus, the award mechanism requires active application. As a result, only cities apply and eventually achieve the flag, while natural and protected areas do not apply, in order to avoid overtourism. Finally, because the Loi Littoral is already implementing beach quality since 1985, the connection between a further external driver such as the Blue Flag and environmental quality is weaker than in other contexts and the impact of Blue Flag remains related to the promotional aspects of tourism.

- The points listed above, the background information proceeding for this and its framing in the social-ecological context would finally respond to the urgent need for specific legal instruments. In fact, even if several European Directives (e.g.2000/60/CE on the water quality; 79/409/CEE for avifauna; 92/43/CEE for habitat conservation; 2008/56/CE on the Marine Strategy Framework) are implemented, their framing in a social-ecological context

\section{Conclusions}

500 The use of the LAZ concept to define meaningful units as the research subject and its consideration in a context like Brittany revealed 1) important information to be retrieved as a baseline for soft sediment coastlines, and 2) directions for a potential extension of concepts, from ecological mesoscale to landscape scale. Firstly, the consideration of substrate characteristics defined the LAZ and was tightly intertwined with both biophysical and social templates. This consideration aligns with the call for broadening the use of the geodiversity concept (Boothroyd and McHenry, 2019), and is especially meaningful when considering physically-driven environments such as soft sediment shores. In practice, information from beach or salt-marsh unit level and including measurements of basic parameters such as beach profiles, granulometry and rocky patches can return extremely powerful integrated datasets.

510 Considering specific features with remarkable relevance both for biophysical and social template,

511 a further recommendation - would be to retrieve baselines of biodiversity for beach units, to be 512 compared with conditions of 1) allochthonous input, including perception and management from 
513 the social template and 2) spatio-temporal use of the resources by endemics and iconic species, 514 including perception and management from the social template.

515 Regarding the up-scaling to landscape ecology, the LAZ concept would likely find a place within the 516 integrated landscape approach framework as defined by Freeman et al.(2015). In this respect, the conceptual extension to salt marshes is likely to open new insights into landscape ecology, supported by a gradient analysis and going beyond the "compare and contrast" approach. On the 519 layout defined by such heterogeneity, the relevance and use of data from management (ranging from tourism exploitation to fish nurseries for commercial value to conservation as seen from the case of Brittany) would be maximized, with a shift to qualitative integrated data (Alexander et al., 2019) for effective a) research on social-ecological systems and b) governance support.

Acknowledgements

The Brittany Region for its financial support throughout the Project 'BOOST Europe' IMPAIR (20192020) and the LTSER ZA Armorique for data sharing.

References

Adams, J.B. 2020. Salt marsh at the tip of Africa: Patterns, processes and changes in response to climate change. Estuarine, Coastal and Shelf Science 237: 106650.

Alexander, S.M., Jones, K., Bennett, N.J., Budden, A., Cox, M., Crosas, M., Game, E.T., Geary, J., Hardy, R.D., Johnson, J.T. and Karcher, S. 2019. Qualitative data sharing and synthesis for sustainability science. Nature Sustainability 3:81-88.

Anfuso, G., Bolivar-Anillo, H.J., Sánchez Moreno, H., Villate Daza, D.A., LópezDaza, O.L. 2018.Coastal Tourism Importance and Beach Users 'Preferences: The "Big Fives" Criterions and Related Management Aspects. Journal of Tourism Hospitality 7:269-2167.

Bird, E. 2000. Coastal Geomorphology. John Wiley and Sons, Chichester, 322 pp.

541 Boothroyd, A., McHenry, M. 2019. Old processes, new movements: the inclusion of geodiversity in biological and ecological discourse. Diversity 11: 216. 
544 Bretagnolle, V., Benoit, M., Bonnefond, M., Breton, V., Church, J.M., Gaba, S., Gilbert, D., Gillet, F., 545 Glatron S., Guerbois, C., Lamouroux, N., Lebouvier, M., Mazé, C., Mouchel, J.-M., Ouin, A., Pays, O., 546 Piscart, C., Ragueneau, O., Servain, S., Spiegelberger, T., Fritz, H. 2019. Action-orientated research and framework: insights from the French long-term social-ecological research network. Ecology and Society 24(3).

Celentano, E., Lercari, D., Maneiro, P., Rodríguez, P., Gianelli, I., Ortega, L., Orlando, L.,Defeo, O. 2019. The forgotten dimension in sandy beach ecology: Vertical distribution of the macrofauna and its environment. Estuarine, Coastal and Shelf Science 217:165-172.

Che, J., Dorgan, K.M., 2010. It's tough to be small: dependence of burrowing kinematics on body size. Journal of Experimental Biology, 213: 1241-1250.

Colombini, I., Aloia, A., Fallaci, M., Pezzoli, G.,Chelazzi, L., 2000. Temporal and spatial use of stranded wrack by the macrofauna of a tropical sandy beach. Marine Biology 136: 531-541.

Courtial, C. 2013. Invertébrés continentaux du littoral sableux breton, poursuite de l'inventaire des dunes et des plages sableuses, évaluation de l'impact d'activités humaines et valorisation des résultats. Contrat Nature, Rapport de synthèse. Conseil Régional de Bretagne, DREAL Bretagne, Conseils Généraux du Finistère, du Morbihan, des Côtes d'Armor et d'Ille-et-Vilaine, 290pp.

Courtial, C., Pétillon, J. 2016. Breton versus British spiders: are they so different? Arachnology, 17: 121-128.

Daniel, T.C., Muhar, A., Arnberger, A., Aznar, O., Boyd, J.W., Chan, K.M.A., Costanza, R., Elmqvist, T., Flint, C.G., Gobster, P.H., Grêt-Regamey, A., Lave, R., Muhar, S., Penker, M., Ribe, R.G., 572 Schauppenlehner, T., Sikor, T., Soloviy, I., Spierenburg, M., Taczanowska, K., Tam, J., von der Dunk, 
Defeo, O.,McLachlan, A. 2005. Patterns, processes and regulatory mechanisms in sandy beach macrofauna: a multi-scale analysis. Marine Ecology Progress Series 295: 1-20.

Defeo, O., McLachlan, A., Schoeman, D.S., Schlacher, T.A., Dugan, J., Jones, A., Lastra, M. and Scapini, F. 2009. Threats to sandy beach ecosystems: a review. Estuarine, coastal and shelf science 81: 1-12.

Defeo, O., McLachlan, A. 2011. Coupling between macrofauna community structure and beach type: a deconstructive meta-analysis. Marine Ecology Progress Series 433: 29-41.

Defeo, O., McLachlan, A. 2013. Global patterns in sandy beach macrofauna: species richness, abundance, biomass and body size. Geomorphology 199: 106-114.

Desender, K., Backeljau, T., Delhaye K., De Meester, L. 1998. Age and size of European saltmarshes and the population genetic consequences for ground beetles. Oecologia 114: 503-513.

de Vos, D., Nel, R., Schoeman, D., Harris, L.R., du Preez, D. 2019. Effect of introduced Casuarina trees on the vulnerability of sea turtle nesting beaches to erosion. Estuarine, Coastal and Shelf Science 223: 147-158.

Dodds, R., Holmes, M.R., 2020. Is blue flag certification a means of destination competitiveness? A Canadian context. Ocean \& Coastal Management 192:105-192.

Dugan, J.E., Defeo, O., Jaramillo, E., Jones, A.R., Lastra, M., Nel, R., Peterson, C.H., Scapini, F., Schlacher, T., Schoeman, D.S. 2010. Give beach ecosystems their day in the sun. Science 329: 11461146.

Dugan, J.E., Hubbard, D.M. 2010. Loss of coastal strand habitat in southern California: the role of 604 beach grooming. Estuaries and Coasts 33: 67-77.

Dugan, J.E., Hubbard, D.M., Page, H.M., Schimel, J.P. 2011. Marine macrophyte wrack inputs and dissolved nutrients in beach sands. Estuaries and Coasts 34: 839-850. 
Dugan, J.E., Hubbard, D.M., Quigley, B.J. 2013. Beyond beach width: Steps toward identifying and integrating ecological envelopes with geomorphic features and datums for sandy beach ecosystems. Geomorphology 199: 95-105.

Dugan, J.E., Emery, K.A., Alber, M., Alexander, C.R., Byers, J.E., Gehman, A.M., McLenaghan, N., Sojka, S.E. 2018. Generalizing ecological effects of shoreline armoring across soft sediment environments. Estuaries and Coasts 41: 180-196.

Earp, H.S., Liconti, A., 2020. Science for the future: the use of citizen science in marine research and conservation. In: YOUMARES 9-The Oceans: Our Research, Our Future (pp. 1-19). Springer, Cham.

Elliott, M., Burdon D., Hemingway, K.L., Apitz, S.E. 2007. Estuarine, coastal and marine systems restoration: confusing management and science -a revision of concepts. Estuarine Coastal and Shelf Science 74: 349-366.

Elliott, M., Day, J.W., Ramachandran, R., Wolanski, E. 2019. Chapter 1 - A Synthesis: What Future for Coasts, Estuaries, Deltas, and other Transitional Habitats in 2050 and Beyond? In: Wolanski, E., Day, J.W., Elliott, M., Ramachandran, R. (Eds.), Coasts and Estuaries: The Future. Elsevier, Amsterdam, pp.1-28.

Fanini, L., Marchetti, G.M., Scapini, F., Defeo, O. 2009. Effects of beach nourishment and groynes building on population and community descriptors of mobile arthropodofauna. Ecological Indicators 9: 167-178.

Fanini, L., Lowry, J.K. 2016. Comparing methods used in estimating biodiversity on sandy beaches: Pitfall vs. quadrat sampling. Ecological Indicators 60:358-366.

Fanini, L., Defeo, O. and Elliott, M., 2020. Advances in sandy beach research-Local and global perspectives. Estuarine Coastal and Shelf Science 234:106646. 
640 Foucreau, N., Renault, D., Hidalgo, K., Lugan, R., Pétillon J. 2012. Effects of diet and salinity on the 641 survival, egg laying and metabolic fingerprints of the ground-dwelling spider Arctosa fulvolineata 642 (Araneae, Lycosidae). Comparative Biochemistry and Physiology Part A: Molecular \& Integrative 643 Physiology 163: 388-395.

Freeman, O.E., Duguma, L.A., Minang, P.A. 2015. Operationalizing the integrated landscape approach in practice. Ecology and Society 20: 24.

Gibson, R.N., Atkinson, R.J.A., Gordon, J.D.M. 2006. Macrofaunal burrowing: the medium is the message. Oceanography and Marine Biology: An Annual Review 44: 5-121.

Giménez, L., Yannicelli, B. 2000. Longshore patterns of distribution of macroinfauna on a Uruguayan sandy beach: an analysis at different spatial scales and of their potential causes. Marine Ecology Progress Series 199: 111-125.

Gül, M.R., Griffen, B.D. 2018. Impacts of human disturbance on ghost crab burrow morphology and distribution on sandy shores. PLoS One 13: 1-17.

Hallermaier R.J. , 1977. Use for a calculated limit depth to beach erosion. XVI Coastal Engineering 660 Conf., pp. 1493-1512

Harris, L., Campbell, E.E., Nel, R., Schoeman, D. 2014. Rich diversity, strong endemism, but poor protection: addressing the neglect of sandy beach ecosystems in coastal conservation planning. Diversity and Distributions 20: 1120-1135.

Harvey Locke, H., Dearden, P. 2005. Rethinking protected area categories and the new paradigm. Environmental Conservation 32: 1-10.

Heery, E.C., Bishop, M.J., Critchley, L.P., Bugnot, A.B., Airoldi, L., Mayer-Pinto, M., Sheehan, E.V., 669 Coleman, R.A., Loke, L.H., Johnston, E.L.,Komyakova, V. 2017. Identifying the consequences of ocean sprawl for sedimentary habitats. Journal of Experimental Marine Biology and Ecology 492: $31-48$. 
Houston, J.R. 2008. The economic value of beaches: a 2008 update. Shore and beach 76: 22-26.

Hubbard, D.M., Dugan, J.E., Schooler, N.K. and Viola, S.M. 2014. Local extirpations and regional declines of endemic upper beach invertebrates in southern California. Estuarine, Coastal and Shelf Science 150: 67-75.

Kadereit, J.W., Arafeh, R., Somogyi, G. and Westberg, E., 2005. Terrestrial growth and marine dispersal? Comparative phylogeography of five coastal plant species at a European scale. Taxon 54: 861-876.

Kneib, R.T. 1984. Patterns of invertebrate distribution and abundance in the intertidal salt marsh: causes and questions. Estuaries 7: 392-412.

Komar, P.D., 1989. Environmental controls on littoral sand transport. In Coastal Engineering 1988 685 (pp. 1238-1252).

686

Leandro, C., Jay-Robert, P., Vergnes, A. 2017. Bias and perspectives in insect conservation: a 688 European scale analysis. Biological Conservation 215: 213-224.

689

Levin, L.A., Talley, T.S. 2000. Influence of vegetation and abiotic environmental factors on salt marsh invertebrates. In: Weinstein, M.P., Kreeger, D.A. (eds), Concepts and controversies in tidal marsh ecology: 661-707. Kluwer Academic Publishing, Dordrecht.

Lowry, J.K.,Fanini, L. 2013. Substrate dependent talitrid amphipods from fragmented beaches on the north coast of Crete (Crustacea, Amphipoda, Talitridae), including a redefinition of the genus Orchestia and descriptions of Orchestia xylino sp. nov. and Cryptorchestia gen. nov. Zootaxa 3709: 201-229. Lessons from and for the Blue Flag award. Tourism Management 48: 211-230. 
Martin, K.S., Hall-Arber, M. 2008. The missing layer: Geo-technologies, communities, and implications for marine spatial planning. Marine Policy 32: 779-786.

McLachlan, A., Jaramillo, E. 1995. Zonation on sandy beaches. Oceanography Marine Biology Annual Review 333: 305-335.

McLachlan, A., Dugan, J.E., Defeo, O., Ansell, A.D., Hubbard, D.M., Jaramillo, E., Penchaszadeh, P.E. 1996. Beach clam fisheries. Oceanography and marine biology: an annual review. Aberdeen University Press/Allen \& Unwin: London.

McLachlan, A., Defeo, O., Jaramillo, E. Short, A.D. 2013. Sandy beach conservation and recreation: guidelines for optimising management strategies for multi-purpose use. Ocean \& Coastal Management, 71: 256-268.

McLachlan, A., Defeo, O. 2017. The ecology of sandy shores. Academic Press.

McLachlan, A., Defeo, O. Short, A.D. 2018. Characterising sandy beaches into major types and states: Implications for ecologists and managers. Estuarine, Coastal and Shelf Science, 215: 152160.

McKenna, J., Williams, A.T., Cooper, A.G. 2011. Blue Flag or Red Herring: Do beach awards encourage the public to visit beaches? Tourism Management, 32: 576-588.

Mendoza-González, G., Martínez, M.L., Rojas-Soto, O.R., Vázquez, G., Gallego-Fernández, J.B. 2013. Ecological niche modeling of coastal dune plants and future potential distribution in

Nordstrom, K.F., 2014. Living with shore protection structures: a review. Estuarine, Coastal and 
Olabarria, C., Lastra, M., Garrido, J. 2007. Succession of macrofauna on macroalgal wrack of an exposed sandy beach: effects of patch size and site. Marine Environmental Research 63: 19-40.

Orr, J.A., Vinebrooke, R.D., Jackson, M.C., Kroeker, K.J., Kordas, R.L., Mantyka-Pringle, C., Van den Brink, P.J., De Laender, F., Stoks, R., Holmstrup, M., Matthaei, C.D. 2020. Towards a unified study of multiple stressors: divisions and common goals across research disciplines. Proceedings of the Royal Society B, 287, p.20200421.

Pearse, A.S., Humm, H.J., Wharton, G.W. 1942. Ecology of sandy beaches at Beaufort, North Carolina. Ecological Monographs 12: 135-190.

Pérès, J.M., Picard, J. 1958. Recherches sur les peuplements benthiques de la Méditerranée nordorientale. In Annales de I'Institut Océanographique de Monaco34, pp. 213-291).

Persson, L.-E. 2001.Dispersal of Platorchestia platensis (Kröyer) (Amphipoda: Talitridae) along Swedish coasts: a slow but successful process. Estuarine, Coastal and Shelf Science 52: 201-210.

Pétillon, J., Georges, A., Canard, A., Lefeuvre, J.-C., Bakker, J.P., Ysnel, F. 2008. Influence of abiotic factors on spider and ground beetles communities in different salt-marsh systems. Basic and Applied Ecology 9: 743-751.

Pranzini, E., Anfuso, G.,Botero, C.M. 2018. Nourishing tourist beaches. In: Beach Management Tools-Concepts, Methodologies and Case Studies. Springer, pp.297-317.

Puzin, C., Pétillon, J. 2019. Contrasted responses of dominant ground-dwelling arthropods to landscape salt-marsh fragmentation. Estuarine, Coastal and Shelf Science 224: 138-141.

Pye K., Blott S.J., 2020. Is ' re-mobilisation' nature restoration or nature destruction? A commentary. Discussion. Journal of Coastal Conservation, 24: 10.

Rey, J., Strong, D. 1983. Immigration and Extinction of Salt Marsh Arthropods on Islands: An Experimental Study. Oikos 41: 396-401. 
Risk, M.J., Moffat, J.S. 1977. Sedimentological significance of fecal pellets of Macoma balthica in the Minas basin, Bay of Fundy. Journal of Sedimentary Research 47: 1425-1436.

Rolfe, J., Gregg, D. 2012. Valuing beach recreation across a regional area: The Great Barrier Reef in Australia. Ocean \& Coastal Management 69: 282-290.

Sardà, R., O'Higgins, T., Cormier, R., Diedrich, A., Tintoré, J. 2014. A proposed ecosystem-based management system for marine waters: linking the theory of environmental policy to the practice of environmental management. Ecology and Society 19:51.

Sassa, S.,Yang, S. 2019. Role of geoenvironmental dynamics in the biodiversity of sandy beaches and sandflats: the ecohabitat chart and its ecological implications. Estuarine, Coastal and Shelf Science 219: 278-290.

Scapini, F., Innocenti degli, E.I., Defeo, O. 2019. Behavioral adaptations of sandy beach macrofauna in face of climate change impacts: A conceptual framework. Estuarine, Coastal and Shelf Science 225: 106236.

Scharma M., Berg M., Olff, H. 2012. Ecosystem assembly rules: the interplay of green and brown webs during salt marsh succession. Ecology 93: 2353-2364.

Schoeman, D.S., Schlacher, T.A., Defeo, O., 2014. Climate-change impacts on sandy-beach biota: crossing a line in the sand. Global Change Biology 20: 2383-2392.

Schlacher, T.A., Weston, M.A., Schoeman, D.S., Olds, A.D., Huijbers, C.M., Connolly, R.M., 2015. Golden opportunities: a horizon scan to expand sandy beach ecology. Estuarine, Coastal and Shelf Science 157:1-6.

Seijo, J.C., Defeo, O.,Salas, S. 1998. Fisheries bioeconomics: theory, modelling and management (No. 368). Food \& Agriculture Organization. 
794 Simpson, M., Clarke, C.S.L.M., Clarke, J.D., Scott, D.,Clarke, A.J. 2012. Coastal setbacks in Latin 795 America and the Caribbean: A study of emerging issues and trends that inform guidelines for 796 coastal planning and development. Washington, DC: Inter-American Development Bank.

Sutton-Grier, A.E., Wowk, K., Bamford, H. 2015. Future of our coasts: The potential for natural and hybrid infrastructure to enhance the resilience of our coastal communities, economies and ecosystems, Environmental Science \& Policy 51: 137-148,

Tinley, K. L. 1985. Coastal Dunes of South Africa 109FRD, CSIR, Pretoria, South Africa, 300 pp.

Trewhella S., Hatcher J. 2015. The Essential Guide to Beachcombing and the Strandline (Wild 807 Nature Press).

808

809 van der Linden, P., Patrício, J., Marchini, A., Cid, N., Neto, J.M., Marques, J.C. 2012. A biological 810 trait approach to assess the functional composition of subtidal benthic communities in an 811 estuarine ecosystem. Ecological Indicators 20: 121-133.

813 Wentworth, C.K. 1922. A scale of grade and class terms for clastic sediments. Journal of Geology 814 30: 377-392.

816 Williams, A.T., Rangel-Buitrago, N., Pranzini, E. and Anfuso, G., 2018. The management of coastal 817 erosion. Ocean \& coastal management, 156, pp.4-20. 
Highlights

1. The concept of Littoral Active Zone of a beach unit was defined in its spatio-temporal dimensions

2. The Biophysical and Social Templates of LAZs were defined generally for beaches and salt marshes

3. The concepts were applied to the case of the coastline of Brittany

4. The LAZ concept proved to be a suitable to define system patterns and drivers 
Table 1. Features of Ecological and Social Templates specifically referring to the Littoral Active Zones of Brittany Region.

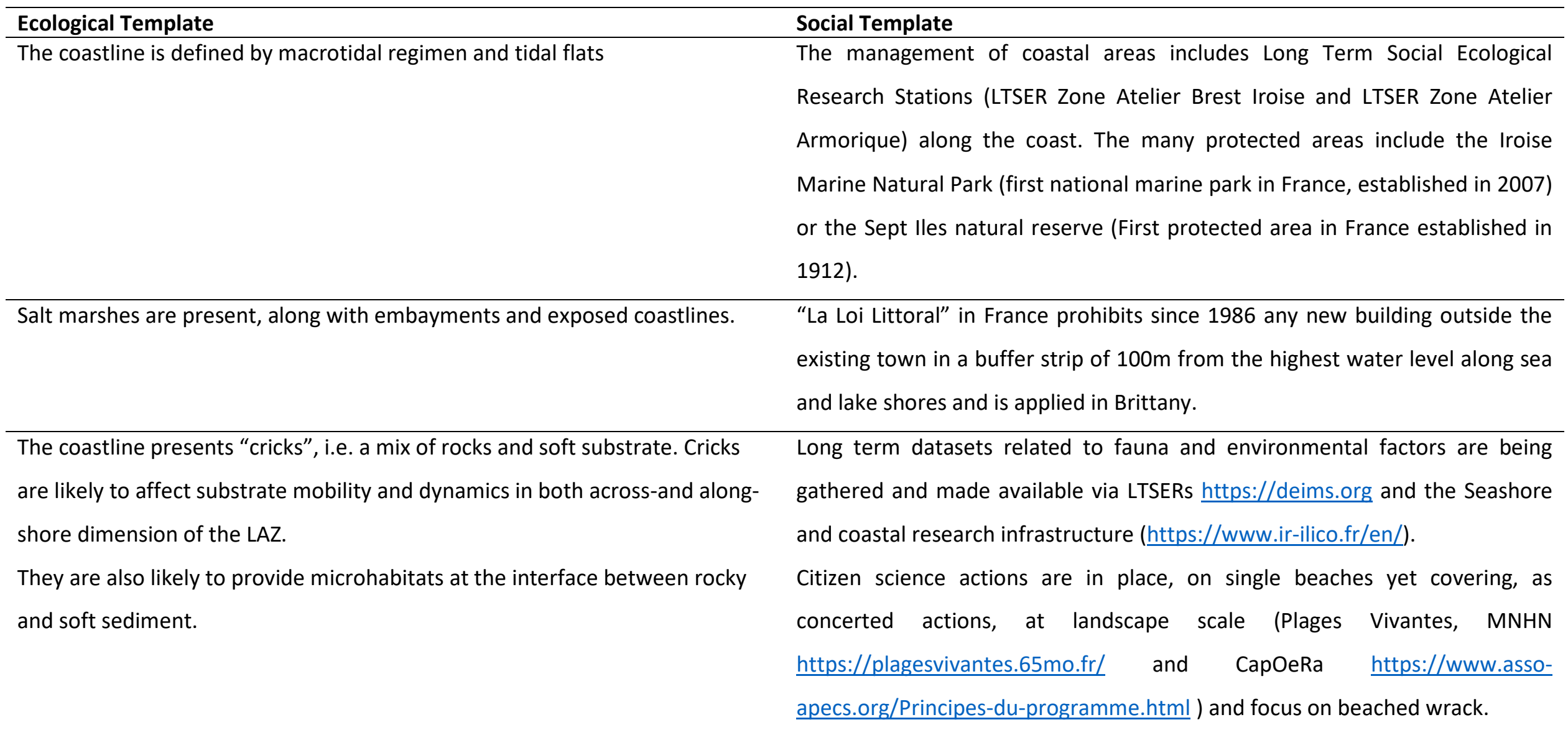

Stranded wrack is a pulse resource (Leroux and Loreau, 2008; 2012), related to the use of beach by a community of invertebrates (i.e. Amphipoda Gammarus locusta, Orchestia gammarellus), Diptera (Coelopafrigida sspp.)) There is a range of management choices related to wrack, with removal that decompose wracks (Zemke-White et al., 2005; Olabarria et al., 2007) and are an important resource for other organisms including iconic species: the 


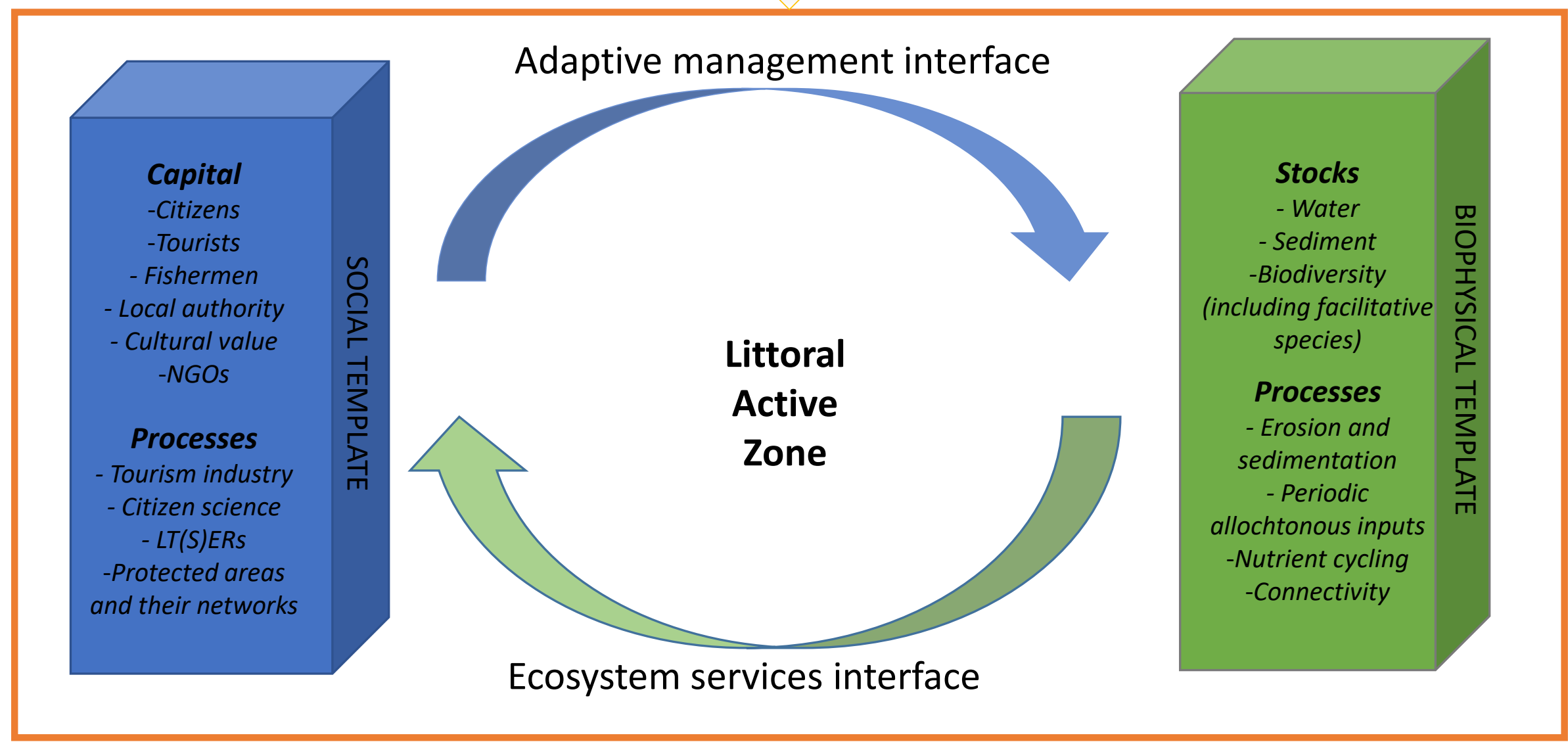


rock Pipit (Anthuspetrosus sspp.) -with a very restricted distribution area limited to the LAZ- and migratory birds for which the decomposer of stranded wrack are a needed resource during their stopover, turnstone (Arenaria interpres) and purple sandpiper (Calidris maritima) (Kerbiriou 2016). Even though there is a lack of studies related to the food-web associated to stranded wrack as pulse resource, this is also hypothesized to be relevant to others terrestrial vertebrates such as toads and bats (Trewhella and Hatcher 2015).

Some beaches are periodically affected by green tides (U/va)(Charlier et al.

2007), which proliferation and accumulation is related to the conjunction of the natural confinement of some shallow water masses, despite the strong tidal movement, and a nitrate terrestrial load from agricultural origin

(Menesguen 1992 but also see https://www.ceva-algues.com/en/ ).
Green tides occur during spring and summer and has been detrimental to recreational use of several beaches of Brittany and consequently in littoral tourism economy (Menesguen 1992).

The region has a high value related to tourism. Brittany is the forth region of France in terms of number of nights for tourism (more than 20 million nights/year of which around 17 million located on the littoral areas after INSEE 2019, see https://insee.fr ). The most attractive touristic localities are the Mont St Michel Bay, the Morbihan Gulf and the Quiberon Peninsula (but also see https://www.brittanytourism.com ).

The cultural heritage of Brittany is also very important to the social template: this is the last region attached to the France kingdom in 1532, but it retained its cultural distinctiveness throughout centuries (e.g. Celtic language, music, traditional dress). 
The "Conservatoire du littoral" is a French governmental organization established in 1975, buying stretches of coastline to apply conservationoriented management while keeping it open to the public. Currently manages $15 \%$ of the French coastline (but see for Brittany http://www.conservatoiredu-littoral.fr/sites-du-littoral/SIL SYCLAD REGION/BRETAGNE/Find/1/5-lessites-du-littoral.htm )

Brittany is the first French region for fishing, with around a half of the national marine production (fish, seafood and algae) (AGRIMER 2019, https://www.franceagrimer.fr ), as well as the first agricultural region of France with $10 \%$ of the national agricultural and fish production (INSEE 2019). 